\title{
Remarks on the Actual Status of Romanian Cinema
}

\author{
By Christina Stojanova
}

Fall 2011 Issue of KINEMA

\section{ROMANIA ON THE MOVIE MAP: REMARKS ON THE ACTUAL STATUS OF ROMA- NIAN CINEMA}

This was my second trip to Romania after more than 20 years, and I was grateful to enjoy the beautiful city of Cluj, the people, the relaxed atmosphere. And certainly the considerate organizers of the festival and its young volunteers! But the most rewarding experience of my trip was watching Romanian films 'on site' that is, in their own context, in the close proximity of filmmakers, film stars, film critics and of Romanian viewers. The round table discussion, hosted by the Romanian Film Critics' association and helmed by Dana Duma, Magda Mihailescu and Mihai Chirilov (artistic director of the Toronto International Film Festival), is yet another congruous - and already traditional - event, where film critics from all over the world gather to compare notes on the status of Romanian cinema. Although I intervened twice in the vivid discussion, what follows is a detailed summary of my afterthoughts on the subject of Romanian cinema as seen at the Cluj film festival.

If the selection of Romanian films - mostly concentrated in the program called Romanian Days - could be considered representative, I would say that, after an almost a decade of consistent international successes, Romanian cinema has reached a professional and aesthetic plateau, promising however to rise towards even more challenging heights. This year has added a few new titles to what we are already used to calling New Romanian Cinema. First and foremost I would like to mention Principles of Life (Principii de viata), second fiction feature of Constantin Popescu, based on one of the best works so far of Razvan Radulescu, the New Romanian Cinema's most popular script writer. Then comes Loverboy, second feature by Catalin Mitulescu (script-writer and director), made in a completely different style from his equally successful debut How $I$ Spent the End of the World (Cum mi-am petrecut sfarsitul lumii, 2006) but quite close in theme and visual aesthetic to If I Want to Whistle, I Whistle (Eu cand vreau sa fluier, fluier, 2010), scripted by Mitulescu for director Florin Serban. Loverboy even shares the same couple of principle actors, featured in If I Want to Whistle - George Pistereanu and Ada Condeescu, who prove again their excellent chemistry. And ranking third in my personal list is Morgen, authorial debut of Marian Crisan, a powerful first feature. Unfortunately, due to a conflict of scheduling I missed Outbound (Periferic, 2010) - yet another allegedly promising first film by Bogdan George Apetri, based on a story by Cristian Mungiu.

While these three fictions are discussed below in more detail, I would like to mention here the innovative documentary Metrobranding (2010) by Ana Vlad and Adi Voicu as a real discovery, thanks to its ability to speak delicately and tactfully about painful, but endemic post-communist processes. The film is structured as talking heads interviews with former managers and workers, unto which historical footage and amusing ex-prompts on the subject - predominantly with young people - are skilfully intertwined, thus exposing in a light and unobtrusive manner a wicked little fact. Purging the collective memory of any and all recollections of Communism and of its material culture, the filmmakers suggest, amounts to a collective amnesia, which threatens the very existence of the nation. Romanian sneakers, Romanian bikes and motorcycles, even Romanian sewing machines - referred to at the time as a tongue-in-cheek euphemism for automatic weaponry, which was also produced in Romania - are but historic relics now, known only to a very few. And, as the film suggests with ironic nostalgia, having lost its know-how in vital industrial areas, Romania is fast becoming a nation of consumers. Some still existing pockets of artisan industry notwithstanding, it is also becoming a nation without memory. ${ }^{(1)}$

Another favourite film of mine, which also takes a well-informed and brilliantly executed shot at the Communist past, but from a hilariously satirical angle, is the experimental fiction Adalbert's Dream (Visul lui Adalbert, 2011), Gabriel Achim's first feature. Since this film merits a lengthy and detailed analysis of its intricate layers of cinematic and cultural intertextual references, all I can say here is that, being familiar with Eastern European totalitarian cinema, I see it as one of the most masterful, meta-cinematic parodies of both the Communist regime and its aesthetic program of Socialist Realism, and would love to be able to show it to my students in Censorship and Propaganda classes. 


\section{The New Romanian Cinema}

Principles of Life, Morgen and Loverboy add yet three more facets of Romanian daily life to the growing number of the so-called New Romanian cinema. And while Morgen and particularly Principles of Life follow its aesthetics of everyday duration scrupulously, Loverboy (and from what I know about Outbound), show a growing impatience and reach for more sensationalist material like trafficking of women and female prisoners, respectively. In any case, the loose formula that brought so much success and world-wide recognition of Romanian cinema does not show signs of wear and tear. On the contrary, it has turned into a challenge and even into a question of honour for story-tellers and directors alike, who compete to come up with new simple stories on Romanian daily life, charged however with multiple layers of meaning.

Marian Crisan's take on the Romanian daily life in Morgen is a good example of how new filmmakers creatively apply this formula. His main character Nelu (András Hatházi) is a nondescript half peasant, half-townsman, who lives on the outskirts of a Romanian-Hungarian border settlement and works as a supermarket security guard for a company, called not without irony Predator Security. Actually, the whole film balances on the verge of dead-pan humour, suspense and existential angst triggered by the sudden change in Nelu's bland routine of early morning fishing, dull and low-paid job, and low key arguments with his chronically unhappy wife. The change is brought on by Nelu's incidental meeting with Behran, a middleaged illegal immigrant of Turkish origin, stuck in Nelu's settlement because of an unsuccessful attempt to cross via Hungary into Germany without papers. The responsibility that comes with taking care of the helpless and amicable Behran, who speaks but a few words of German (one of them being the eponymous 'morgen', or morning), their growing friendship, and last but not least - the cynicism of the border police which pretends illegal immigrants do not exist in order to avoid the hassle of taking care of them - force Nelu out of his phlegmatic resignation into an act of sheer heroism. The Hungarian-Romanian actor András Hatházi as Nelu is a real discovery, and it is his stubborn albeit mostly silent determination that stirs the backwater settlement out of its perennial inertia and makes it root for Behran. And, when some weeks later the so much anticipated 'morgen' comes, Nelu - risking prison and even his life - helps him cross the border into Hungary, we also find ourselves hoping against hope that he would soon reunite with his family in Germany.

Similarly deceptive in its simplicity is Principles of Life, where - in Radulescu's familiar manner - we are made privy to the daily routine of another middle-aged man, Emilian (featuring the 'fetish' actor of the New Romanian Cinema, Vlad Ivanov). Unlike Nelu, he could be considered the epitome of success: an extrovert of the bullish type, highly opinionated, divorced and re-married to a beautiful young wife, and a father of a sweet baby boy. And yes, he lives in Bucharest, has a well-paid job in the printing business, a nice car, a spacious apartment and is in the process of building a suburban house. But as luck - and Radulescu's narratives - usually have it, this picture-perfect life crumbles on the eve of Emilian's long planned and well deserved vacation with his young family and his teen-aged son from the first marriage. It is actually the latter's acting up which triggers Emilian's unravelling, exposing deep-seated cracks in his personality and his appalling emotional neediness. And although the cruel climactic scene is of Emilian thrashing his son in a fit of rage, he is actually punishing himself for being an emotional failure and unable to really connect with any of the people he loves. When the camera leaves him in the car, headed to the seaside with everyone aboard, we are made painfully aware that nothing would ever be the same for Emilian. Vlad Ivanov offers one of his best performances by pulling out all the emotional stops in soliciting viewers' active response. He masterfully moves from endearing his character by swaggering madly his beer belly (the actor put on more than twenty pounds for the role) in the unforgettable kitchen stunt of a Romanian rock singer, to making him particularly detestable for his misguided machismo, culminating in the beating of his son. Yet whether one justifies or condemns Emilian, he would nonetheless remain a memorable character thanks to his highly contradictory nature, masterfully brought to life by Ivanov.

The third male character of note is Luca, the eponymous dark narcissistic charmer from Loverboy, who also faces a serious crisis but of quite a different nature. For one, he is in his late teens or early twenties and does not belong to the immediately knowable social and psychological types as Nelu or Emilian. Yet although he inhabits the criminal demi-monde, he cuts an uncannily familiar figure of a handsome boy from the social margins, condemned to a life of crime not so much by social circumstance as by complacency and a sense 
of entitlement that usually comes with smashing looks. Luca's unusual metier is to make beautiful innocent girls fall in love with him and then sell them into sexual slavery to tougher pimps who dispose of them as they please. The film begins with the tail end of a previous love story, with Luca in a police line-up because of a complaint by one of his victims. However the girl, obviously still in love, spares him at the last moment only to be later beaten to death for her 'betrayal' by Luca's 'business' partners. The film then embarks on revealing in detail the mechanism of Luca's 'business' pursuits or more specifically, how he goes about corrupting his beautiful girlfriends. What makes this film transcend its sensationalist media impetus is the fact that the author does not compromise his rigorously realistic approach and refuses to present his hero as a victim, which could absolve him of responsibility for his moral and emotional ruthlessness. Despite the dire social context of his existence - Luca comes from a very poor village, where young people are either chased away by the total lack of perspective or lured into crime and prostitution by the seductive life-style of the nearby Constanta, the beautiful resort town on the Romanian Black Sea coast - he is fully aware of the consequences of his acts, whose gravity could hardly be redeemed by the devoted care he takes of his infirm grandfather.

Thanks to his complexity, drawn with no concessions to commercial or social sentimentality, Mitulescu's Luca is inducted into the unique gallery of characters yielded by the New Romanian Cinema. And, not unlike Emilian and Nelu - the other two most recent inductees - Luca flaunts the perfect balance of what Aristotle calls the universal - that is, his globally knowable features - and of the particular - that is, the ones tied to the historical time and space of Romania circa 2010. This admixture could be brought to life only by a powerful actor - in this case George Pistereanu - a young actor with captivating silent presence. Like Ivanov's Emilian and Hatházi's Nelu, his Luca is an unusual character in usual circumstances, generating conflicting emotions in the viewer, fluctuating between sympathy and aversion, identification and opposition. Pretty much like his Silviu, the reckless convict who ruins his life for love of the wrong girl in If I Want to Whistle, I Whistle.

\section{Other Trends}

Hopefully, these brief discussions have so far proven my argument that the New Romanian cinema stays the right course. The very fact that the two other tendencies, represented in the selection of Romanian films at the festival - the high modernist art-cinema and the so-called popular, or commercial one - did not come up with anything original or intriguing, supports my point by proxy. The much awaited Sinisa Dragin's new film Daca bobul nu moare (If the Seed Doesn't Die, 2010), co-produced by Romania, Serbia and Austria, made in the grand-opera metaphoric style of Kusturica's Time of the Gypsies (1988) and especially Underground (1995), and influenced by the intricate imagery of Tarkovsky's late works, came as a real disappointment, despite the stunning visuals of its DOP Dusan Joksimovi. Indeed, special attention merit his unforgettable images of an Orthodox church doggedly dragged by Romanian villagers for miles on end - two hundred years ago the building of Orthodox churches was forbidden in parts of Romania - only to see it sink under the cracking ice of a lake. As a staunch fan of Dragan's film from 2001 Everyday God Kisses Us on the Mouth ( $\hat{I} n$ fiecare zi Dumnezeu ne saruta pe gura), I was clinging to this image and its wonderful symbolism. Ironically however, it was also sunk under the burden of the film's cluttered narrative, overwhelmed by characters and metaphors, some of which - like the father forced to rape his own daughter in order to save her - came through not as the extremely profane opposite to the sacerdotal image of the sunk church, but as a tasteless and even offensive speculation.

The only film I saw from the so-called commercial trend was Phantom Father (Tatal Fantoma, 2011), although its commercial viability is yet to be proved in the box-office. Its script is based on auto-biographical story by American script-writer Barry Gifford who, among others, has to his credit the scripts of David Lynch's Wild at Heart (1990) and Lost Highway (1997). Being of Romanian origin, he not only scripted the film, but also starred in the cameo role of the sceptical boss of the middle-aged American professor who goes back to contemporary Romania to search for his roots, but finds the love of his life amongst the post-communist chaos. However, not unlike Dragin's film, this debut work by Lucian Georgescu is cluttered to the point of confusion by plot lines and characters, and has a hard time to decide whether it is a nostalgic, dream-like narrative about the end of cinema as we know it (à-la Tornatore's Cinema Paradiso, 1988) or a Hollywoodstyle, May-December romantic comedy with a bitter Eastern European edge. Or all of the above, something like an updated version of Amarcord (Fellini, 1973) with a wide popular appeal, which - unfortunately - it 
fails to become.

And yet, when writing about the Actual Status of the Romanian cinema, one should remain perfectly aware that, if it were not for the films of the New Romanian Cinema, works like If the Seed..., Phantom Father and the others I have not the time to analyze or mention here, would have constituted the actual image of that cinema; something one is compelled to mull over before being unreasonably critical of the New Romanian films for, among other reasons, not being commercially successful.

\section{Viewer's Cinema: the Case of Odessa in Flames}

If commercial success becomes the most important criteria for a national cinema - and for its cultural artifacts in general - then one should look no further than the case of Odessa in Flames (Odessa in fiamme), which eloquently exposes the traps of such an attitude. The long lost Italian-Romanian co-production from 1942, directed by Carmine Gallone, was shown at a special screening in Cluj. In their desire to attract as many viewers as possible - and to thus please their respective pro-fascist governments - Gallone et co., ignored the best contemporaneous achievements not only of art, but also of popular cinema. While ignoring the first Neo-Realist film, Luchino Visconti's Ossessione (Obsession), released in the same year, was quite understandable since they probably had not even heard of it, the filmmakers were most likely well aware that intelligent Romanian viewers at that time were familiar with such accomplished and highly popular works of the interwar cinema as Classical Hollywood cinema, French Poetic Realism, and the professionally crafted German popular cinema, its heavy ideological bias notwithstanding. Yet having targeted the lowest common denominator of viewers' taste, the makers of Odessa in Flames came up with the tritest possible melodramatic, ideological and ethnic stereotypes, which make the film even more unwatchable than telefoni bianchi, the fashionable Italian films of the time. It must have indeed been more frustrating for Romanians from the 1940s to watch this film than it was for its viewers in Cluj circa 2011. For its original viewers were denied the relief of historical and political distance, which made this infantile spectacle at least laughable for us now, rather than demeaning as it must have been back then.

\section{Coda}

Some Notes on the Strategies of Survival of Small National Cinemas (summary of my verbal argument at the actual round-table discussion).

In my view, the only way for survival of the so called 'small' national cinemas (like the Romanian or Canadian) would be to produce the so-called small (that is, low-budget) films, which, out of necessity, flaunt realist aesthetics and small casts, but are able to play with various narrative devices. The most successful small (and not-so-small) national cinemas so far have developed their own original aesthetics - the Danish Dogme 95, the Iranian theocratic and Korean visceral realism, etc. In fact, the ability of a national cinema to survive is now measured by the ability of its (predominantly young) directors to move as far away from Hollywood as possible (which, by the way, is the path followed by the American independent directors). Such is the case with the cinema production of my adoptive country, Canada.

After the National Film Board (NFB) settled comfortably in the documentary film niche it carved out of Hollywood in the 1940s - and got the first ever Oscar for documentary film for Churchill's Island in 1941 - it then steadily moved towards becoming the world animation-producing centre. Only afterwards, in the 1970s, did the NFB launch the Canadian fiction film industry. Canadian cinema continues to be a poor relative to American cinema - in the famous dictum of the former Canadian Prime Minister Pierre Elliott Trudeau, "sleeping with an elephant". Canadian film production is allotted only about 3 percent of the country's screening time, 94 percent of which goes to Hollywood films, and the remaining 3 percent to films from the rest of the world (including the few Romanian ones that have recently been distributed here). And although the attempts to support Canadian commercial cinema continue, it has not been economically successful in English-speaking Canada. This being said, no matter how counter-intuitive it may sound, English Canadian directors persist in their effort to make films and to sustain a number of creatively vibrant provincial film industries, despite all the odds.

As for French-speaking Quebec, it enjoys a flourishing film industry - which produces commercially successful art and popular cinema alike, thanks, of course, to the generous federal and provincial subsidies. But Quebec is a special case, and its example could hardly be used as a model elsewhere unless national cinemas become regarded by both politicians and audiences as one of the scarce and cherished expressions of a besieged and 
threatened national identity along the lines of Quebec's self-perception as a Francophone cultural island in the North American English-speaking ocean. In other words, only when there is a consensus on all social levels that the national cinema - as the national culture - is the most precious symbolic capital, part and parcel of the physical survival of the nation vis-à-vis the onslaught of cultural globalization, could a small national production replicate the success of Quebecois cinema.

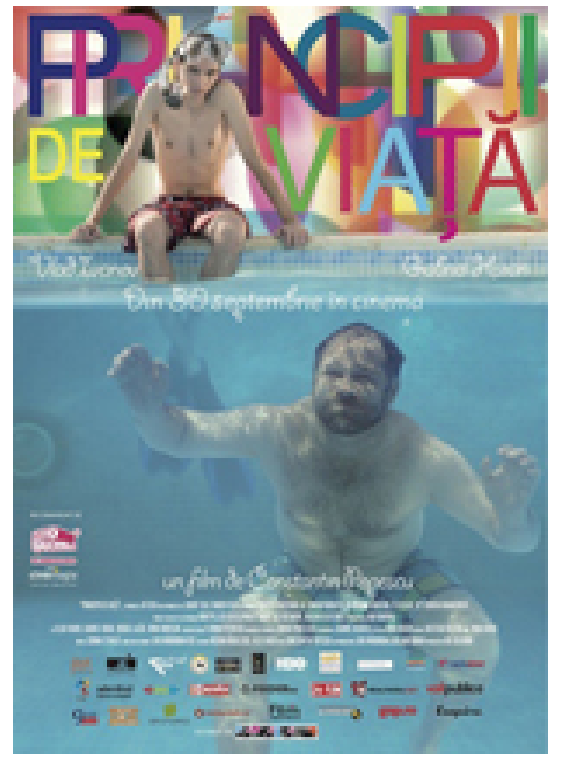

Figure 1: Principles of Life by Constantin Popescu (publicity poster)

\section{Notes}

1. The other documentary worth mentioning is Close to Heaven (Aproape de cer/Dem Himmel ganz nah) by Titus Faschina (2010), co-produced with Germany. While it tackles similar issues of memory and forgetting, its visuals are way too stylized in the poetic manner of a biblical narrative, thus considerably blunting its cultural and social urgency.

\section{Author Information}

Christina STOJANOVA teaches at the Department of Media Production and Studies at the University of Regina, Canada. She has contributed to Cine-bulles, KinoKultura, and the Montreal Gazette. Her publications include chapters in Berlin Culturescapes, Making it Like a Man: Canadian Masculinities, Eastern European Cinema, Traditions in World Cinema, Horror International, Alternative Europe and Cinema and Globalization. 